\title{
Deluxe Devotional Prayer Books: A McGill Book of Hours
}

\author{
by Maria L. Brendel
}

Books of Hours are the most common and the most popular of medieval manuscripts. In the McGill University Libraries' Department of Rare Books and Special Collections there is a particularly fine example of a Book of Hours-Medieval MS 109. This Manuscript is unusually small and has exquisite illuminations. This article will introduce MS 109 and its genre, the Book of Hours.

Les livres d'Heures sont les manuscrits médiévaux les plus courants et les mieux connus. Le Département de livres rares et de collections spéciales des bibliothèques de l'Université McGill possède un exemplaire particulièrement remarquable de livre d'Heures-Médiéval MS 109. Ce manuscrit est exceptionellement petit et comporte des enluminures d'une rare beauté. Cet article présente MS 109 et son genre, le livre d'Heures.

ILLUSTRATIONS, pages 82-90.

I n McGill's Rare Books Collection there is a gem of a manuscript known as Medieval MS 109. ${ }^{1}$ It is described in the De Ricci Census ${ }^{2}$ as follows:

109. Officium B. [eate] V. [irginis] Mariae. Ve.[ellum], ca. $1510,170 \mathrm{ff}$, $8 \times 6 \mathrm{~cm}$. Written in Flanders. Illum. borders, 6 large miniat., Italian Russia leather, ca. 1830, (bound for G.S.). Given by Dr. Casey A. Wood.

In light of the scarcity of documentation on this manuscript its pictures serve as a guide to locate a place of origin. In a memorable phrase the English 'art critic' John Ruskin, in the last century, affirmed that "illumination is only writing made beautiful." To this he added "the moment illumination passes into picture making it has lost its ... function. ${ }^{\prime 3}$ The pictures in this manuscript refute Ruskin's claim.

MS 109 belongs to those manuscripts, small and detailed, aesthetic masterpieces, of which one monk exclaimed "it is a killing work," to produce. ${ }^{4}$ And a scribe left the following words: "Dear reader in turning over these pages with your fingers, take care not to damage the writing; no one who is not a calligrapher can have an idea of the labour involved." 5

Devotion and hard labour it was. Every step was carried out manually. This included the preparation of vellum, collation of folios, ruling of pages, the script, 1llumination and binding. In the early stages writing and decorations may have been done by the same person. With ever increasing demand for manuscripts in the later part of the Middle Ages labour was divided among scribes and illuminators (illustrators). Initially, book production was exclusively monastic. Scriptoria were attached to the large monasteries of Monte Cassino, St. Martin of Tours, Echternach, Winchester and St. Albans. ${ }^{6}$ However, from the thirteenth century onwards the manufacture of books became increasingly secularized and independent of monastic control. Workshops were set up in the larger towns where scribes and painters organized themselves into guilds.? The formation of town ateliers was in parallel with the increasing demand for the Book of Hours (Horae).

When MS 109 was created, illumination was in its last flowering as a competitor claimed its stake: the printing press. But interestingly, just when movable type made economical the mechanical production of books, a Flemish painter revolutionized manuscript illumination by introducing a painting technique never seen before: trompe l'xil, illusionistic borders and a window-like treatment of space, done in particularly lustrous colours. ${ }^{8}$ This new development replaced the borders of earlier manuscripts in which wire thin plants appeared, in matte colours and restrained modelling. The effect was largely two-dimensional in contrast to the new three-dimensional borders. ${ }^{9}$ Manuscript production was prolonged.

The innovator-whose name remains so far unknown - was the Master of Mary of Burgundy who created 
between 1475 and 1477 two Books of Hours for Mary of Burgundy and her husband the Archduke Maximilian (MS 78 B 12, Berlin: Kupferstichkabinett, Staatsbibliothek; and cod. 1857, Vienna: Österreichische Nationalbibliothek). ${ }^{10}$ In these two books he introduced the new painting technique. $M S$ 109 features these novelties. Here the painted motifs give the illusion of opened windows surrounded by borders of fruit, birds, flowers and insects. The effect is that of a bee crawling over the page or a flowerhead or strawberry just having been dropped on it. Naturalism at its best. This type of page construction was also adapted in secular manuscripts: the Roman de la Rose (New York, Pierpont Morgan Library, ms. 948). ${ }^{11}$

From the pictorial evidence, MS 109 was produced after the Hours of Mary of Burgundy, most likely in the early years of the sixteenth century, by a workshop that produced very small Books of Hours. ${ }^{12}$

\section{BEST-SELLER}

Books of Hours are considered by some twentieth century scholars to be medieval best-sellers, ${ }^{13}$ due to their popularity all over Europe. Significantly, almost all exemplars independent of their place of origin, feature one common language: Latin. They are prayerbooks-a composite of texts-owned by men and women living secular lives, of different social standings. Even those who were unable to read, aspired to own one ${ }^{14}$ Not all Horae included pictures, there are humble versions. They were referred to as Primers of which an English grocer said: "my prymer with gilt clasps, whereupon I am wont to say my service. "15 The Book of Hours with its prayers and hymns, provided a link on a personal level to God, the Virgin, Angels, Prophets, Saints and Patron Saints.

P. Ganz claims that despite the manuscript's use as a private devotional book, illuminated versions were luxury objects. They existed on a scale such that the book moved back and forth from being a Wertobjekt (valuable object) to a useful prayerbook. ${ }^{16}$

The popularity was such that Books of Hours form the largest category of illuminated manuscripts now extant. Even after the Middle Ages, when Horae fell out of popular use as religious sentiments changed, Books of Hours were collected by bibliophiles. The Flemish painter-diplomat Peter Paul Rubens, for example, had one in his library ${ }^{17}$-likely an inheritance. In the eighteenth and nineteenth centuries, some collectors, after purchasing a Book of Hours on the art market, had pictures painted of themselves while in the act of reading (Auguste de Chatillon: Leopoldine au Livre d'Heures, 1835, Maison de Victor Hugo, Paris). ${ }^{18}$

\section{CHEMISETTE}

Some Books of Hours give information about the date and place they were made, occasionally about the scribe, the miniaturist and owner in ways of diary entries and coats of arms. In MS 109 these opening pages are missing. The book, in its current state, starts with the Calendar pages. Possibly, folios containing a name of the owner or user were lost or discarded when the book was rebound over the centuries for a new owner. The current binding of 'Russia leather,' was added in the nineteenth century and was surely preceded by others. Initially, Books of Hours, especially small ones, were not covered with thick leather to stabilize the outer pages for placement on a shelf. Rather, the covers were bound in silk or velvet to be carried in the users pocket or purse. The spine, known as the pippe was most often decorated with pearls to which bookmarks were attached. ${ }^{19}$ The book, when completed was usually sewn into a covering, the chemisette, which was either of kid-leather, silk-fabric or velvet. When picked up by the corners the chemisette formed a bag. ${ }^{20}$ When laid open on a prayer table, or held in the supplicant's hands, the chemisette functioned like a napkin to protect the pages. ${ }^{21}$ This reconstruction is possible with the aid of panel pictures and folios from Horae (Robert Campin: Triptych of the Annunciation, fifteenth century, Metropolitan Museum, New York: and the Hours of the Master of Mary of Burgundy, Cod. 1857, folios: "The Virgin and Child Worshipped," and "Christ being Nailed to the Cross"). ${ }^{22}$

\section{INCOMPLETE}

Despite loss and destruction during the centuries a substantial number survive today in public and private collections still in book format, some in fragments-in leaves, often torn out on grounds of their aesthetic 
appeal and separated from the text to which the pictures belong. One such horrible deed was carried out by none other than Ruskin who recorded in his diary: "Spent the day cutting up a missal, hard work. ... Put two pages of missals in frame. $" 23$

That the luxurious MS 109 came down to us with its pictures-of tempera ${ }^{24}$ on folios covered with gold leaf-is no small feat. The book includes six leaves with miniatures and sixteen folios featuring elaborate border decorations and painted initials. In addition, it also includes two leaves with pictorial capitals, and a large number of folios with extraordinary calligraphic embellishments and numerous initials written in 'pure' liquid gold (giving letters a sculptural effect). (Fig. 1) Surely, the book's small size $(8.5 \times 6.5 \mathrm{~cm})$ allowed it to be tucked away, safely, over the centuries by bibliophiles who, unlike Ruskin, were receptive to the manuscript's historical significance as a whole. The book format itself shielded the light-sensitive illuminations, which in manuscripts are not covered by the protective layers of varnish that panel paintings have.

\section{'OBSECRO TE'}

Despite MS 109's good state of preservation the manuscript has not reached us complete in terms of its prayers and miniatures. Eight folios have been removed of which four were most likely texts, the rest miniatures. A leisurely browsing through the book does not show this loss. But, a careful examination of the quires (collations of folios) shows stubs left behind of the cut-out or torn-out pages. Also, a close look at the text reveals missing folios.

Almost all Books of Hours include the two long and special prayers to the Virgin beginning respectively with Obsecro te, domina (I implore thee) and $O$ intemerata (O matchless one). ${ }^{25}$ In some Horae they are placed before the Hours of the Virgin, although the content of the book could be arranged freely. In $M S$ 109 the prayers appear after the Office of the Dead. Unfortunately, the folio commencing Obsecro te is no longer there. But since folio 162 starts $O$ intemerata, the prayer Obsecro te was also included. Without a doubt, Obsecro te commenced after folio 157, where the stub indicates a torn out leaf. The following textual leaves are part of this prayer. A reconstruction of the missing miniatures will follow below. Despite this loss, $M S 109$, with its one hundred and seventy folios of which nearly all are used recto and verso-except the miniatures-delights the beholder with its illumination and consistent script on such small scale, which is surprisingly easy to read.

Unlike earlier and larger manuscripts written in the angular Gothic script, $M S 109$ features the Italianate rounded lettering, the rotunda, developed by scribes in the Papal chancellery and by humanist scholars. ${ }^{26}$ This script was preferred for small manuscripts to facilitate reading. The same script, for example, is used in the slightly larger Horae, a Flemish manuscript attributed to Simon Bening (Book of Hours, MS. L. 39-1981, London, Victoria and Albert Museum). ${ }^{27}$

\section{ILLUMINARE}

Illumination refers to the pictorial aspects of a manuscript. The word derives from the Latin illuminare to 'brighten' or 'light up' the text. ${ }^{28}$ This comprises the fancy penwork of initials, versets (decorative line endings), border decorations and miniatures. The materials used are precious metals, gold, often valuable pigments (indigo blue and azurite as seen in the Virgin's mantle) and different coloured inks. ${ }^{29}$

Miniatures are pictures in manuscripts. They can be full page or they can take the form of a picture set into elaborate border ornamentations as in $M S$ 109. The word 'miniature' does not mean 'small.' It derives from the Latin word minimum, the red pigment (lead oxide) used by scribes in the Middle Ages to emphasize letter initials on folios. ${ }^{30}$ And miniare meant to write or paint in vermilion (red); the artist doing so was called the miniaturist. ${ }^{31}$ Hence the word miniature.

Historiated or pictorial capitals are enlarged initials into which a small picture, often figurative, the ystorie, is painted. On the last leaves of $M S 109$ two such historiated initials - using the letter $\mathrm{O}$-are included on folios with border decorations. The first one depicts the Christ child enthroned, flanked by a kneeling John the Baptist. ${ }^{32}$ The other shows a standing St. Athanasius to whom the prayer on this page is directed. St. Athanasius may have been the patron Saint of the owner 
whose birthday, perhaps, was May second, the Saint's feast day. ${ }^{33}$ These folios, however, hold a surprise: their border decorations are left incomplete, a sudden interruption? (Fig. 2)

The embellishments-miniatures, borders, historiated capitals and pen-flourishes-produce a sparkling effect which makes the act of praying, at least on the pictorial level, a devotional luxury.

\section{HORAE}

Until the Book of Hours came into existence, in the thirteenth century, there were beside the Bible, servicebooks used in the celebration of the mass. These manuscripts, some of which had pictures, of which Ruskin's deed informs us, were the Breviary, Missal and the libri corali, books for musical chants. ${ }^{34}$ One text that may have been available to the laity were the Psalms. ${ }^{35}$

Horae developed from the texts of the Breviary and Missal both of which were part of the liturgy. The Breviary included the Hours of the Virgin, also called the 'Little Office of the Virgin'-Officium parvum beate Marie Virginis. But, unlike the Breviary or the Missal (the latter containing the texts necessary for the Mass) which were used by priests or persons in religious orders, the Book of Hours was for the laity, for personal devotions, independent of the liturgy. ${ }^{36}$

The origin of the Marian prayers, is not sufficiently clear. Services to the Virgin took form among the Benedictines, in the tenth century, and spread from the monasteries to the laity. ${ }^{37}$ This increase in worship was parallel to the re-assessment of the Virgin's role within the established hagiography. ${ }^{38}$ Especially during the later part of the Middle Ages her position changed from a mere intercessor to Queen of Heaven, "coredemptrix" with Christ. ${ }^{39}$ By the time the Book of Hours was formed the devotions to her and her role in the redemption of one's soul was fully established. However, the inclusion of the Little Office in the Breviary and its official recitation in church proved insufficient. There was a need among lay people for a prayerbook to be used in one's private sphere-in which images could be included - that would allow a relation to the Virgin on a personal level..$^{40}$ This need generated the Book of Hours.
Yet, while the Hours of the Virgin forms the centre of the Book it included from the beginning secondary texts (some extracted from the Missal). These are the Calendar pages, reminding the user of important feast days, holidays, anniversaries and the consecration of local churches. ${ }^{41}$ They include Saints venerated in the region in which the Book was produced. The entries were in black and red ink to distinguish the more important (red letter days) from the less important ones. The Calendar is followed by the Sequentiae of the Gospels; the seven Penitential Psalms; the Litany to Prophets, Angels and Saints; the Office of the Dead and the Memoriae to various Saints (including patron and local Saints). ${ }^{42}$ All of these Offices are included in $M S$ 109.

The Hours of the Virgin were modelled after the canonical hours and divided into daily prayer services which, in illuminated versions, as in MS 109, include miniatures and elaborate border decorations at the beginning of each Hour. The following is a breakdown of this arrangement. Parallel to the hours are the miniatures with their themes (indicating also the missing folios): ${ }^{43}$

\begin{tabular}{|c|c|c|}
\hline Matins & (said between midnight and 6 a.m.) & Annunciation \\
\hline Lauds & (also midnight to 6 a.m.) & Visitation \\
\hline Prime & $\begin{array}{l}(6-9 \text { am. }) \\
\text { missing in MS } 109\end{array}$ & Nativity \\
\hline Tierce & $\begin{array}{l}\text { (9 a.m. - noon) } \\
\text { missing in MS } 109\end{array}$ & $\begin{array}{c}\text { Annunciation to } \\
\text { the Shepherds }\end{array}$ \\
\hline Sext & $\begin{array}{l}\text { (noon - } 3 \text { p.m.) } \\
\text { missing in MS } 109\end{array}$ & $\begin{array}{l}\text { Adoration of the } \\
\text { Magi }\end{array}$ \\
\hline Nones & $(3-6$ p.m. $)$ & $\begin{array}{l}\text { Presentation in the } \\
\text { Temple }\end{array}$ \\
\hline Vespers & $(6-9$ p.m.) & $\begin{array}{l}\text { Massacre of the } \\
\text { Innocents }\end{array}$ \\
\hline Compline & (9 p.m. - midnight) & $\begin{array}{l}\text { Coronation of the } \\
\text { Virgin }\end{array}$ \\
\hline
\end{tabular}

The forth miniature cut out of MS 109, was at the beginning of the Office of the Dead, as the remaining stub near the string indicates. The facing folio is intact commencing the Office of the Dead with the habitual prayer Placebo domino in regione vivorum (I will praise the Lord in the land of the living). ${ }^{44}$ In a comparative Horae the miniature shows the interior of a church, candles lit, where this 'Office' is being celebrated by several ecclesiastics with a small attending crowd, dressed in black (Simon Bening (attributed): Book of Hours, MS. L. 39-1981). ${ }^{45}$ 


\section{A McGill Book of Hours}

The Office of the Dead was to be said every night, which for a postmodern beholder may appear to be a morbid occupation. Considering the traumatic experience, recurrent plagues and the memory of the Black Death, a pre-occupation with death becomes more understandable. It was important to know how to die well. ${ }^{46}$

Saints were instrumental as intercessors and their names appear prominently. But before discussing the local Saints included in MS 109 the Use of the Book of Hours needs mentioning. In liturgiology, a Use is a distinctive form of prayer and ritual followed in a particular church or diocese. ${ }^{47}$ Most Flemish Books are of Roman Use. Some French exemplars have Parisian Use (in France there are others as well). In England Books of Hours are usually of the Sarum Use. ${ }^{48}$ The variations that make these distinctions are rather minor: the order of prayers, arrangements of hymns, variations in text among others. MS 109 is of Roman Use.

\section{SAINTS}

The Calendar pages in MS 109 include local and English Saints: St. Amandus of Maastricht (584-679), feast day February sixth) was a missionary bishop who preached in Flanders and found several religious houses, most notably in Ghent. St. Juliana (born ca. 309, feast day February sixteenth) is a martyr, whose bones are in the church of Lady of Sablon, in Brussels. St. Gertrude (626-659, feast day March seventeenth) was an abbess of Nevilles and venerated in the Lowlands. Her feast day is celebrated at Louvain and in the duchy of Brabant.

The English Saints include St. Augustine of Canterbury (died 605, feast day May twenty sixth). He was a missionary bishop establishing his see at Canterbury where he founded a monastery. Of St. Leonard there are two, one whose date is unknown (feast day is November sixth). He was a hermit honoured in France, Germany and England. The other lived around 559 (with the same feast day) venerated in Yorkshire. St. Machar (sixth century, feast day November thirteenth) preached in Aberdeenshire. ${ }^{49}$

\section{ATELIERS}

The inclusion of Saints honoured in the Lowlands and the painting techniques used in $M S 109$ point to Flanders as a place of origin. This is confirmed by yet another feature. Characteristic of Flemish Books of Hours is a miniature at the beginning of the Penitential Psalms of David in Penitence. ${ }^{50}$ (cover image, Fig. 3) Significantly, MS 109 also includes such a picture which depicts David kneeling, with his lyre beside him. Distinctly Flemish, also, is the use of symbolism: objects (flowers for example) have meaning going beyond formal appearance.

The artists who produced MS 109 were from the Ghent-Bruges school of painting, known as the GhentBruges Associates. ${ }^{51}$ An illuminator from this late period of manuscript production, whose name we know among the many anonymous masters, is Simon Bening (1483-1561).$^{52}$ He was active in the early decades of the sixteenth century and the last leading artist of the Ghent-Bruges School. The painting techniques of the Master of Mary of Burgundy were equally characteristic of him and his workshop. ${ }^{53}$ To him and his atelier several manuscripts have been ascribed among them the Grimany Breviary (c. 1520, Venice: Biblioteca Marciana) ${ }^{54}$ and a fragmented Book of Hours (MS. L. 39-1981, London: Victoria and Albert Museum); its script (rotunda) and miniature-Office of the Dead -we have mentioned above. ${ }^{55}$ Both of these books vary greatly in size from each other yet both incorporate, trompe l'aeil and symbolism. It is possible that MS 109 is the product of this atelier made by illuminators who specialized in small manuscripts.

There are observations that support this attribution. The church interior of MS 109's Presentation (Fig. 4) miniature is similar to that of the Office of the Dead of 'MS. L 39-1981.' Both have detailed Gothic windows, and both include the same stout man (strikingly similar) who in the Presentation stands to the right of the Virgin, likely Joseph or possibly Simeon. One could argue that illuminators copied from one another or used model books which existed. ${ }^{56}$ However, MS 109 features a complex pictorial scheme and a stylistic luxury-a product of a learned workshop. 


\section{A McGill Book of Hours}

The attribution of MS 109 to a foremost atelier can be suggested by another observation. The elaborate pen flourishes in red and black ink on initials throughout the text are almost identical-albeit in a smaller version-to those in the Hours of Philip the Good, Duke of Burgundy, 1454-55 (The Hague: Koninklijke Bibliotheek, ms. 76, f. 2,). ${ }^{57}$ The fact that such embellishments are featured in MS 109 is indicative of an atelier where illuminators/scribes not only knew about the decorations of princely commissions but were experienced well enough to do them themselves. (Fig. 5)

The illluminations in MS 109 were carried out by different hands. It appears that the borders were painted by one artist, the miniatures by another, and the painted initials likely by a third, something not unusual in Books of Hours (several hands are detected in the Grimany Breviary). ${ }^{58}$ Interestingly, the miniatures are the only leaves not used on both sides which indicate that they must have been inserted when the text pages (and their design) were complete. Yet, the miniature leaves are in close relation with their facing folios: for their borders include the same select objects. When read symbolically a complex iconographic scheme is revealed.

\section{MINIATURES}

The six miniatures of MS 109 are set in arched frames which extend to the top of the pages. They are surrounded by illuminated borders of which the outer side is wider then the inner. The writing is surrounded by border illustrations on all sides. Yet, in contrast to the miniatures the text is arranged in a rectangular shape and appears to be visually closer to the border. This effect is especially apparent in the Annunciation (Fig. 6), Massacre (Fig. 7) and David miniatures where the gold round of the border expands into the text onto which large initials are painted. As well, these textpages appear flat throughout. Even the illuminated borders are flat, for the flowers and animals have a three dimensional quality extending towards the beholder. Here, the painted reality of insects, birds and flowers are projected into the space of the reader. This illusion is achieved through the use of sbadows, opaque colours and thick applications of paint, and the use of highlights to delineate and decorate. It is the illuminator's device to involve the beholder/reader.
The miniatures, by contrast, are visually separated from the borders by a thin, dark line, conveying the effect of a panel picture. Both the painted realm of the pictures and border illuminations have no relation in terms of proportion. In fact there is a disparity in scale between the borders and miniatures (although this disparity breaks down for a reader/beholder familiar with both the visual symbolism and the text). The miniatures have a concave effect and recede into space, away from the beholder. They are windows which open either into a bedchamber and church-Annunciation and Presentation-or onto a northern European landscape-Visitation, Massacre and David.

It is interesting how the Flemish illuminator used a northern setting for the biblical narrative. This is seen in the minutely rendered particulars: the Gothic windows of the church interior, and the priest's gold vestments with a fur collar, seen in the Presentation. A most tender gesture occurs in the Visitation picture when Elizabeth touches the belly of the Virgin as the two women stand near an archway outside a medieval town. ${ }^{59}$ (Fig. 8) This tender scene contrasts with the horrific subject of the Massacre of the Innocents where a young mother's anguish is so effectively rendered-her howl becomes almost audible ${ }^{60}$-as she bemoans her dead child. As she stands looking at the beholder communicating her grief to us, while tearing her hair, the murderers retreat on a winding road into the distance. In contrast to these emotional 'earthly,' events the Coronation of the Virgin takes place in an undefined space-a heavenly sphere-where an angel holds a crown over the kneeling Mother of God. (Fig. 9)

In the last miniature, David wears what appears to be a monk's habit. But since his vestment has gold highlights a royal garb is signified. Beside him, on the ground is a fur hat, a delightful inclusion by the illuminator who was concerned to the keep the king warm in a northern climate. This picture also includes an accurately painted 'wattle fence,' typical of the Lowlands. This became the subject of a study for Rubens, a century later (Landscape with a Wattle Fence, ink drawing London: British Museum, No. 75).$^{61}$ The subject of David in Penitence challenged the painter to turn this miniature into a landscape scene-a fascinating one on such small scale-which extends far into the distance with its winding river and bridge beside a row of bouses, a forest and a brooding sky. 
This cloudy sky befits the penitent mood of the scene.

Interestingly, the Annunciation is the only miniature in MS 109 in which details, mostly the face of the Virgin, are no longer visible. The picture is worn on this particular spot, perhaps from touching or from kissing by a devout user.

\section{EMBLEMATIC READING}

An emblematic reading of the borders buttresses the narrative contents of the miniature. In some instances the objets are uniconic, 'stand ins' for a religious persona.

The first illuminated page, and the only one, to include red carnations, is folio $13^{\text {r }}$. (Fig. 10) This page commences the prayer Domine labia mea (Lord open my mouth) leading into the Sequentiae of the Gospels which comprise the Passion. Carnations in late medieval symbolism were the flowers of the Passion of Christ. In its flower and bud the nail of the crucifixion were seen. ${ }^{62}$

This folio, like all others with illustrated borders, has references to the Virgin. The border includes violets and small, wild strawberries. In Partheneia Sacra-a seventeenth century book based on earlier texts describing the select inhabitants of the garden of the Incomparable Virgin Marie Mother of God-the violet is spoken of as being "truly the Hermitesse of flowers ... a lowlie humilitie mixed with solicitude. Behold the violet who grows wel in Our Ladyes Garden, an excellent Type or Symbol of her. ${ }^{113}$ Strawberries, like violets, grow humbly in the underbrush. When represented together they bespeak bumility and true righteousness. The violet and strawberry are symbols of the fruit of the spirit. ${ }^{64}$

On folios $32^{v}$ and $33^{r}$ Matins begins with a miniature of the Annunciation. Each folio includes in its borders white roses, violets, and strawberries and peacocks. Since the peacocks are not repeated in any subsequent page their representation is 'place-specific.' The peacock is the bird of paradise, symbolic of the immortality of the soul, the ever vigilant. ${ }^{65}$ In its tail all colours blend with which the idea of totality is expressed. ${ }^{66}$ Read in association with the miniature in which Christ is announced, the peacock is the emblem of Christ, salvation, hence paradise.

White roses in MS 109 appear always plain, unlike the red rose, which are decorated with gold. White roses refer to the Virgin's purity and appear, likewise, unadorned in a comparative Horae (Soane Hours, Ghent-Bruges School, ms. 4, ff. 97v-98r, London: Sir John Soane's Museum). ${ }^{67}$ The Partheneia Sacra in poetic form provides a contemporary meaning of both the white and red rose:

The Virgin spring even from the barren earth,

A pure white Rose was in her happie birth,

Conceav'd without a thorne. This onlie flower

The Father rays'd by His Almighty power.

When th'Angel said, she should conceave a

Sonne,

She blused, and asked, how it should be donne?

The Holie Ghost inflam'd, and so the white

By him was made a Damask firie-bright.

Lastly her Sonne made her purple red,

No Faith of Mortals then but had a staine,

Excepting hers; for she was died in graine. ${ }^{68}$

The bee, included in the large initial, is also a symbol of the Virgin. "The Bee ... feeds no worse then of the deaw, that falls from Heaven.... Just so our Ladie, not taken by the bayts and allurements of this world, for spiritual life, lived of the heavenlie deaw of Divine grace. "69 Further, the Mother of God is likened to the insect for "she was the Bee, the Hive her Sacred Womb."70 There is yet another parallel. Bees were believed to be parthenogenic and so signified virginity and chastity. ${ }^{71}$

The borders of the Visitation miniature and those on the facing folio $51^{r}$ feature the pea flower prominently. This lesser known motif recurs in the borders of the Massacre and David miniatures as well, although in smaller numbers. The pea flower has several meanings including modesty and bumility signified by the flower's plainness. The pea flower is emblematic of fertility, as pointed out by J. Plummer in his discussion of the Hour Book of Catherine of Cleves (MS. 917, New York: Pierpont Morgan Library). ${ }^{72}$ The flower also symbolizes wisdom (the pea is featured at the Hour of Wisdom-Matins-Ms. 782, Baltimore: Walters Art Gallery) ${ }^{73}$ In the Middle Ages peas and similar legumes were the 'bread' of the poor, and thus the pea, as 
bread, symbolized the Eucharist. ${ }^{74}$ The pea flower, then, is a parallel to Christ as life-giving force, and renewal. ${ }^{75}$ The pea can also be interpreted as a symbol of the spirituality of a prophet. A medieval commentator on Daniel's refusal to eat meat in favour of legumes sees this as a metaphor of the prophet's spirituality. ${ }^{76}$ David, in the biblical narrative has prophetic functions. The pea flower surrounding the miniature of David in Penitence may, therefore, symbolize his spirituality. ${ }^{\pi}$

Red roses with elaborate gold delineations are included in the borders of the Presentation and Massacre miniatures, with one, also, in the border of the Coronation. Here, the gold decorations alone indicate a higher rank. The red rose's symbolic meaning is partly made clear in the verses above. Significantly, each time the rose appears the flower is in full bloom. This parallels the appearance of Christ in the pictures. Just as Christ is being presented to the high priest, so is the red rose to the beholder. This flower is also symbolic of martyrs, the 'massacred innocent children,' who like the gold covered roses, have reached a heavenly position. In an altarpiece by Jan van Eyck (Ghent Altarpiece, 1432) red roses grow under the martyrs. ${ }^{78}$

The rose grows in the Virgin's garden, too, of which is said: "the odour she gave-forth of her Sanctitie ... [is] the odour of thy garments. "79 The rose is also the flower of eternity, the queen of flowers emblematic of the Virgin who in the Coronation is becoming: regina coeli (queen of heaven). ${ }^{80}$

The columbine, selected for the borders of the Presentation and Coronation is rendered almost scientifically, like a botanical specimen, to ensure recognition. In $M S 109$ the columbine is distinguished by one aspect: gold delineations-real gold-which raise the flower to a higher level of meaning. The columbine is emblematic of the Holy Spirit, and its seven blooms are the gifts thereof. ${ }^{81}$

Acanthus leaves surround only one miniature: the Coronation. But unlike the red rose or the columbine, acanthus leaves are not decorated with gold. But they claim their presence in boldness and quantity. Acanthus is the plant of the garden of heaven, an emblem of immortality.$^{82}$ This plant, then in its supporting role to the miniatures clarifies for the reader/beholder that the Coronation of the Virgin takes place in a heavenly sphere.

Birds, as well, are inhabitants in the Virgin's garden, particularly the male nightingale who sings in the night. Judging from the engraving in the Partheneia Sacra, the bird positioned in the borders of the David miniature, at the height of the fence, is the nightingale. ${ }^{83}$ This bird can be linked to David. "The Nightingale is the little Orpheus of the woods, ... that hath for Lyre the litle Clarigal, or Organ of his throat. "84 It "sings his Anthems and prettie Alleluyas," like David. It is ... a "Hermit for the most part ... and contemplative. ${ }^{85}$ The Virgin too, is likened to a nightingale:

For Marie arising went into the mountains, and so became

the Nightingale... She inhabited not the fens or marshes or marishes of dissolute lubricitie, abode not in the playnes of an ordinarie vertue, but left

the vallies of baser cogitations, aspired to the tops of Heroical vertues, placed the nest in the sublimitie of

Divine contemplations and dwelt in the top of the mount of

Perfection; whence proceeded that sweet voice, more sweet then anie mortal harmonie... ${ }^{86}$

\section{EFFECT}

The initial visual disparity between border and miniature, and the layers of spatial reality break down entirely. The reader/beholder, at first attracted aesthetically, is now set up for a dialogue that takes place on several levels. Once raised to a symbolic level, the objects of the borders are in dialogue with the text, by which, ultimately, a dialogue with the reader/beholder is established.

It remains to be asked how illuminations affected the contemporary beholder. What were the images' functions? Of course, religious sensibilities were different when compared to our technological age. And the mystique which the Book of Hours held for each 
devout user is hard to juxtapose into our own time. Yet it is worth trying to situate the pictures vis à vis a late medieval supplicant.

As recent writers have reminded us, pictures in medieval books performed a range of functions. ${ }^{87} \mathrm{On}$ the one hand they sharpened the visual interest of the page by interrupting the flow of the written word. ${ }^{88}$ And on the other hand they highlighted important places (functioning as bookmarks) and ranked the prayers and Offices. They served to mark the canonical divisions. Illumination helped to clarify the hierarchical ordering of the prayers, especially the Marian prayers. ${ }^{89}$ Those with pictures clearly indicated the importance they had to the patron in relation to the other devotional texts without images. ${ }^{90}$

Picture and word were in conversation with one another collaborating in intricate ways, ${ }^{91}$ which $M S 109$ confirms. But could the image function independently of its textual accompaniments? J. Naughton answered this question in the following way: "The rubric of the prayers always refer to the efficacy of saying the prayer itself" for which an emotional state is suggested. ${ }^{92}$ The "rubrics merely state that the prayer should be said ... buono et puro cordo"(well and with a pure heart), which indicates a certain devotional state. ${ }^{93}$ The pictures were not the cleansing agents to gain a pure heart, although they could function as a stimulus. Thomas of Canterbury recited prayers cum magna devotione (with great devotion). ${ }^{94}$ It would seem that for the actual recitation of the prayers pictures were not necessarily needed. ${ }^{95}$ But they provided devotional exemplars. Miniatures with their figurative content facilitated access to the religious personae. As well, pictures were able to draw the supplicant into the painted realm through narrative content, and technique. A tranquil scene stretching into the distance provided a quiet mood needed for devotion. ${ }^{96}$ Most of all, the-Marianpictures triggered a physical presence of a tenderly accessible Mother and Child, inviting the supplicant to shared intimacy. ${ }^{97}$

Would Ruskin have changed his mind?

\section{Notes}

1. Thanks are due to Professor Rosemarie Bergmann who pointed me to McGill's manuscript collection and ultimately to MS 109; Dr. Richard Virr who freely gave of his time, answering questions and who allowed me to use his research file; and to Maurene White Elliot and Akram Faizer whose suggestions I included.

2. Seymour De Ricci, Census of Medieval and Renaissance Manuscript in the United States and Canada (reissued New York: Klaus Reprint, 1961), 2213.

3. 'Lectures on Art V,' cited: John Harthan, Books of Hours and Their Owners (London: Thames and Hudson), 1977, 19, henceforth referred to as Harthan, Owners.

4. He belonged to the monastery of St Aignan of Orleans: P. D'Ancona \& E. Aeschlimann, The Art of Illumination. An Anthology of Manuscripts from the Sixteenth Century (New York: Phaidon, 1069), 1969, 11.

5. Ibid., 11.

6. John Harthan, An Introduction to Illuminated Manuscript (Owings Mills, Maryland), 1983, 7; henceforth referred to as Harthan, Introduction.

7. Ibid., 7 ,

8. Otto Pächt, The Master of Mary of Burgundy (London: Faber and Faber Limited), 1948, 24.

9. T. Kren, ed. Renaissance Paintings in Manuscripts. Treasures from the British Library (New York: Hudson Hill Press), 1963, 3.

10. Pächt, 24.

11. M. Voelkle, ed., Masterpieces of Medieval Painting. The Art of Ilumination (Chicago: The University of Chicago Press), 1980, see microfiche included in this book.

12. Thomas Kren in an unpublished MA thesis attributed ten Books of Hours to a workshop specializing in the production of very small manuscripts. "A Book of Hours in the Beinecke Library (ms. 287) and an Atelier from the Ghent-Bruges School," Yale University, 1974. Roger S. Wieck, Late Medieval and Renaissance llluminated Manuscripts 1350-1525 in the Houghton Library (Cambridge Mass., : Harvard College Library), 1983, 58. There must have been several ateliers producing small books. De Ricci 109 does not stem from this workshop because its miniatures employ 'windows' with a greater spatial illusionism.

13. Among them is the late L.M.J. Delaissé one of the first scholars together with the Abbé Leroquais to research Books of Hours. Harthan, Owners, 19, 175.

14. Ibid., 31 .

15. From an English Archive, Ibid., 34.

16. Peter Ganz, ed., The Role of the Book in Medieval Culture, Proceedings of the 1982 Oxford International Symposium, Series Bibliologia Elementa AD Librorum Studia Pertinentia, vol. III (Brepols: Turnhout), 1986, 196.

17. Sigrid Macrae, "Rubens' Library," MA Thesis, New York: Columbia University, 1971 (books are listed in alphabetical order). 
18. For collectors and art dealers see A.M.L. Munby, Connoisseurs and Medieval Miniatures 1750-1850 (Oxford: Clarendon Press), 1972, fig. 1. An 'Heures de la Vierge, Flamande,' ca. 1480, strikingly similar to $M S 109$, is listed in a sales catalogue in, 1986, for 250.000 Franc, circa CND $\$ 47,500$, Manuscrit Livres anciens et contemporains Autograph, de Paul Schrag de New York et de Deux Autres Collectionneurs vente aux enchères publiques a Paris, 1986; information taken from R. Virr, Research File.

19. Harthan, Owners, 36-37.

20. Ibid., 39.

21. Ibid., 37.

22. Pächt, figs. 12-13.

23. J. Ruskin, Collector," The Library, xxi, 1966, $125 \mathrm{ff}$ : Harthan, Owners, 36, 177.

24. Tempera is egg yolk mixed with pigments.

25. M.R. James, "Points to be observed in the Description and collation of manuscripts, particularly Books of Hours," A descriptive catalogue of the manuscripts in the Fitzwilliam Museum (Cambridge: 1895), xix-xli, xxiv; R. Virr provided me with this article. Harthan, Owners, 15.

26. Harthan, Introduction, 7.

27. Ibid., fig. 36 .

28. Ibid., 6.

29. Cennino Cennini, Il Libro del Arte, trans. D.V. Thompson (New York: Dover Publications), 1960, 35.

30. Harthan, Owners, 20.

31. Ibid., 20.

32. R. Virr, Research File.

33. He was bishop of Alexandria from 328-373. New Catholic Encyclopaedia (New York), 1967, 996.

34. Harthan, Introduction, 12.

35. M.R. James xxv. For other medieval texts see: Pamela Gehrke, Saints and Scribes. Medieval Hagiography in its Manuscript Context (Berkeley: University of California Press), 1993, 12 ff.

36. Harthan, Introduction, 12 and Owners, $13 \mathrm{ff}$.

37. M.R. James, xxv.

38. "Chapter IV: "Die lehrhafte Weiterbildung des Marienglaubens im Mittelalter,' Marienbild (Exhibition catalogue, Essen: Villa Hügel), 1968, 25 ff.

39. Ibid.

40. Harthan, Owner, 14.

41. Ibid., 15-16.

42. Ibid., 14, 18.

43. M.R. James, xxvi.

44. Harthan, Owners, 18.

45. Harthan, Introduction, fig. 20, p. 36.

46. Harthan, Owners, 17.

47. Ibid., 19.

48. The variations by which a Use can be determined are given by M.R. James, xxvi ff.

49. The information of the Saints given here was taken in part from an unpublished paper: J.M. Samson, "Book of Hours in the Redpath Library, de Ricci 109," McGill University, 1969 , 2-3; and R. Virr, Research File. Part of the information stems also from: D.H. Farmer, Dictionary of Saints (Oxford: Clarendon Press), 1978) and Reclams Lexikon der Heiligen und der biblischen Gestalten. Legende und Darstellung in der bildenden Kunst (Stuttgart: Philipp Reclam jun.) 1984.

50. Kren, Renaissance, 6.

51. Wieck, 50. The founder of this school was, of course, the Master of Mary of Burgundy, Pächt, 24.

52. Harthan, Introduction, 36.

53. Ibid., 34.

54. D'Ancona \& Aeschlimann, 228, fig. 123.

55. Harthan, Introduction, 36.

56. An incomplete manual is the 'Göttingen Model Book' of the fifteenth century which has written instructions and painted specimen, Harthan, Owners, 23.

57. Harthan, Owners, 104, fig. 102-3.

58. D'Ancona \& Aeschlimann, 228.

59. A similar Visitation miniature is included in: MS Richardson, f.9, Book of Hours (Houghton Library, Harvard University), Wieck, p. 56.

60. James, unpublished paper, R. Virr, Research File.

61. W. Adler, Corpus Rubenianum Ludwig Burchard, Landscapes (Oxford: University Press), 1982, fig. 161.

62. "In Blatt und Frucht der Nelke erkannte man die Nägel der Kreuzigung Christi." G. Heinz-Mohr, Bilder und Zeichen der Christlichen Kunst (Cologne), 1971, 221.

63. John Cousturier, Partheneia Sacra or The Mysterious Garden ... Al to the Honoyr of the Incomparable Virgin Marie Mother of God for the Pleasure and Devotion, 1633 (reissued by Aldington Kent), 1950, 38, 42.

64. Heinz-Mohr, 9; Steven Olderr, Symbolism (London: McFarland), 1986, 131; J.C. Cooper, An Illustrated Encyclopedia of traditional Symbols (London: Thames and Hudson), 1978, 162.

65. Ad De Vries, Dictionary of Symbols (Amsterdam), 1974, 360.

66. J.E. Cirlot, A Dictionary of Symbols (London: Routledge \& Kegan Paul), 1984, 233.

67. Harthan, Owners, 153.

68. Cousturier, 25.

69. Ibid., 74, 78 .

70. Ibid., 78.

71. Cooper, 19.

72. J. Plummer, Liturgical Manuscripts for the Mass of the Dead and the Divine Office (New York: The Pierpont Morgan Library), 1964, $45 \mathrm{ff}$.

73. Lillian Randall, "Pea-Pods and Molluscs from the Master of Catherine of Cleves Workshop," Apollo, November), $1974,372$.

74. Rosemarie Bergmann, "Sicut lillium inter spinas: Pflanzen als Symbolträger," Mittelalter Rezeption Symposium (Stuttgart: date?), $455 \mathrm{ff}$.

75. Ibid., 456-457. 
76. Ibid., 457.

77. Interestingly, some folio's of the Roman de la Rose include pea flowers in their border decorations.

78. Bergmann, 455 .

79. Cousturier, 24.

80. De Vries, 391.

81. Olderr, 91.

82. De Vries, 3.

83. The other birds included in this border need to be dealt with in a subsequent study.

84. Cousturier, 139

85. Ibid., 140.

86. Ibid., 145.

87. Vera F. Vines, "Reading Medieval Images," in Medieval Texts and Images. Studies of Manuscripts from the Middle Ages, ed. M. Manion and B. Muir (Sydney: Craftsman House), 1991, 127.

88. Ibid., 127.

89. Joan Naughton, "A Minimally Intrusive Presence: Portraits in Illustrations for Prayers to the Virgin, "Ibid., 117. 90. Ibid., 112.

91. Vines, 127

92. Ibid., 113.

93. Ibid., 113.

94. Naughton, 112.

95. Ibid., 112.

96. Naughton, 117. Vines, 128.

97. Naughton, 111. 